\title{
Genetic transformation of gentian Gentiana tibetica (King) leaf explants with Agrobacterium tumefaciens strain C58C1
}

\author{
Anna I. Wójcik ${ }^{1} \cdot$ Jan J. Rybczyński ${ }^{1}$
}

Received: 27 April 2016/Revised: 4 October 2016/Accepted: 14 December 2016/Published online: 22 December 2016

(C) The Author(s) 2016. This article is published with open access at Springerlink.com

\begin{abstract}
Experiments were carried out on transformation of leaf explants derived from the axenic culture of Gentiana tibetica (King) using a co-culture of Agrobacterium tumefaciens. A. tumefaciens octopine strain $\mathrm{C} 58 \mathrm{C} 1$ carried neomycine phosphotransferase (nptII) and $\beta$-glucuronidase (uidA) genes. The influence of plasmid helper pCH32 on transformation efficiency was stressed. After co-cultivation, explant was cultured on three different regeneration media (RM1-3) at the presence of the timentin and callus formation and plants regeneration occurred. The transgenic character of the selected tissue and transformants $\mathrm{T} 0$ in the presence of kanamycin has been confirmed by the histochemical analysis of reporter enzyme activity (ß-glucuronidase), polymerase chain reaction, and southern hybridization detecting uidA and nptII genes. L-glutamine used during inoculation period had a significant influence on the transformation efficiency in relation to its concentration and time of treatment.
\end{abstract}

Keywords Gentian · Transformation · Agrobacteriummediation $\cdot$ L-glutamine $\cdot$ Transformation efficiency

\section{Abbreviations \\ PCR Polymerase chain reaction}

Communicated by H Peng.

Jan J. Rybczyński

jjryb@obpan.pl

Anna I. Wójcik

aiwojcik@wp.pl

1 Department of Experimental Plant Biology, Botanical Garden-Center for Biological Diversity Conservation, Polish Academy of Sciences, ul. Prawdziwka 2, 02-976 Warsaw, Poland

$\begin{array}{ll}\text { nptII gene } & \text { Neomycin phosphotransferase gene } \\ \text { uid A }(g u s) \text { gene } & \text { Glucuronidase gene } \\ \text { MS medium } & \text { Murashige and Skoog medium } \\ \text { Kin } & \text { Kinetin } \\ \text { NAA } & \text { Naphtaleneacetic acid } \\ \text { BAP } & \text { Benzylaminopurine } \\ \text { DNA } & \text { Desoxyribonucleic acid } \\ \text { 2,4-D } & \text { Dichlorophenoxy acetic acid } \\ \text { Dicamba } & \text { 3,6-Dichloro-2-methoxybenzoic acid } \\ \text { AS } & \text { Adenine sulfate } \\ \text { GA }_{3} & \text { Gibberellic acid }\end{array}$

\section{Introduction}

We have been presenting a series of papers describing experiments carried out on gentian transformation paying attention on the morphogenic potential of the organ, tissue, cell suspension, and its protoplasts in post-transformation cultures (Wójcik and Rybczyński 2015). This paper focuses on G. tibetica (King) leaf explants transformation with the help of A. tumefaciens.

Out of 1600 species of the family Gentianaceae, only 12 Gentiana species were investigated with the help of biotechnological methods and there are not many papers concerning G. tibetica. For the species, the first publication focused on vegetative propagation (Skrzypczak-Pietraszek et al. 1993) and showed the process of shoot multiplication from hypocotyl explants in the presence of B5 agar medium (Gamborg et al. 1968) supplemented with $0.5 \mathrm{mg} / \mathrm{l}$ Zeatin with the multiplication ratio reached over 10 buds per explant. The somatic embryogenesis was developed on an MS medium supplemented with $0.5 \mathrm{mg} / \mathrm{l}$ 2,4-D $+1.0 \mathrm{mg} / \mathrm{l}$ Kinetin (Wesołowska et al. 1985), when the most responsive explant appeared to be hypocotyls derived 
from axenic seedlings (Hosokawa et al. 1997; Quing et al. 2006; Ishimaru et al. 1990; Mikuła et al. 1996). The hypocotyl explants, as the most embryogenic among others, gave over 100 embryos, on average. Switching the type of culture from agar solidified to liquid medium resulted in the establishing of an embryogenic cell suspension culture of several gentian species including G. tibetica and unlimited number of somatic embryos was produced during few year-long cultures (Mikuła and Rybczyński 2001).

With the help of $A$. rhizogenes, transformation experiments have been described for some species of the family Gentianaceae: Blecstonia perfoliata, Centaurium erythraea, Eustoma grandiflorum, Gentiana acaulis, G. cruciata, G. lutea, G. macrophylla, G. purpurea, G. punctata, G. scabra Line TP1, G. scabra Bunge var. Buergeri Maxim, G. trifora $\times$ G. scabra cv. Polano and cv. Polano Bluc, and Swertia japonica. (Bijelović et al. 2004; Piątczak et al. 2006; Subotić et al. 2003/2004; Handa 1992; Handa et al. 1995; Giovannini et al. 1996; Momčilović et al. 1997; Tiwari et al. 2007; Zhang et al. 2010; Vinterhalter et al. 1999; Menković et al. 2000; Mishiba et al. 2006; Suginuma and Akihana 1995).

In the case of A. tumefaciens, the following gentians were the objective of transformation: E. grandiflorum, $G$. cruciata, G. dahurica, G. kurroo, G. punctata, and G. trifora $\times$ G. scabra cv. Polano-White and cv. Albireo (Takahashi et al. 1998; Chen et al. 2010; Semeria et al. 1996; Hosokawa et al. 2000; Nishihara et al. 2006).

In addition, for gentian transformation, two non-vectorial methods such as biolistic and electroporation were employed. The particle bombardment of seedling explants of E. grandiflorum (Takahashi et al. 1998) and cell suspension of G. trifora $\times$ G. scabra was successfully used (Hosokawa et al. 2000). The electroporation of G. kurroo protoplasts derived from embryogenic cell suspension resulted in transformant regeneration via somatic embryogenesis (Wójcik and Rybczyński 2015).

An earlier improved morphogenic potential of gentian leaves and their mesophyll cell protoplasts (Fiuk and Rybczynski 2008a, b; Tomiczak et al. 2015, 2016) forced us to develop transformation system of leaf blade explants of axenic cultured $G$. tibetica with A. tumefaciens strain C58C1 carried neomycin phosphotransferase (nptII) and $\beta$ glucuronidase (uidA) genes (Fig. 1 and Map of plasmids). Because of very rich secondary gentian metabolite production characterized by aseptic value, the helper plasmid pCH32 carrying virG and virE genes and various concentrations of L-Glutamine were used for improving transformation efficiency.

\section{Materials and methods}

The experiments were carried out according to the diagram presented in Fig. 1.

\section{Plant material and its culture}

The axenic culture of $G$. tibetica was maintained in a plant growth chamber at a temperature of $20 \pm 1{ }^{\circ} \mathrm{C}$ with light intensity $150 \mu \mathrm{E} \mathrm{m}^{-2} \mathrm{~s}^{-1}$ and photoperiod $16 / 8 \mathrm{~h}$ (day/ night). The culture of transformed leaf explants was carried out in the darkness.

\section{Explant origin and medium}

Explants were derived from a leaf blade of axenic culture of G. tibetica (16-week-old). Leaves of third whorl were perpendicularly excised (to main vascular bundle) giving the explants. Explants were implanted on agar MS medium (Murashige and Skoog 1962) supplemented with various ingredients depending on the carried on experiments (Table 1), and $\mathrm{pH}=5.6$ was adjusted before autoclaving. Each petri plate was poured with $20 \mathrm{ml}$ of media.

\section{$\beta$-Lactam antibiotics (timentin and cefatoxime) effect on leaf explant response}

For the Agrobacterium elimination from cultures, following concentrations $0,100,150,200,250$, and $300 \mathrm{mg} / 1$ of studied antibiotics were tested. Their effect on the morphogenic potential of explants was also investigated. Eighty leaf explants (with 16 explants per plate) were implanted on AIM1 and AIM2 media supplemented with a particular antibiotic concentration. The cultures were maintained in the dark at $20 \pm 1{ }^{\circ} \mathrm{C}$ during 4 weeks. After that period, they were evaluated paying attention to callus proliferation and necrosis observed on the explant surface.

\section{Kanamycin concentration testing for leaf explants}

The following kanamycin concentrations $0 ; 25,50,75$, and $100 \mathrm{mg} / \mathrm{l}$ (medium KSCM2) were tested to point out the selection concentration for explants. The effect of particular concentrations was evaluated with the help of the morphological changes observed in the explant. For establishing transgene selection, an optimal kanamycin concentration was later applied. 


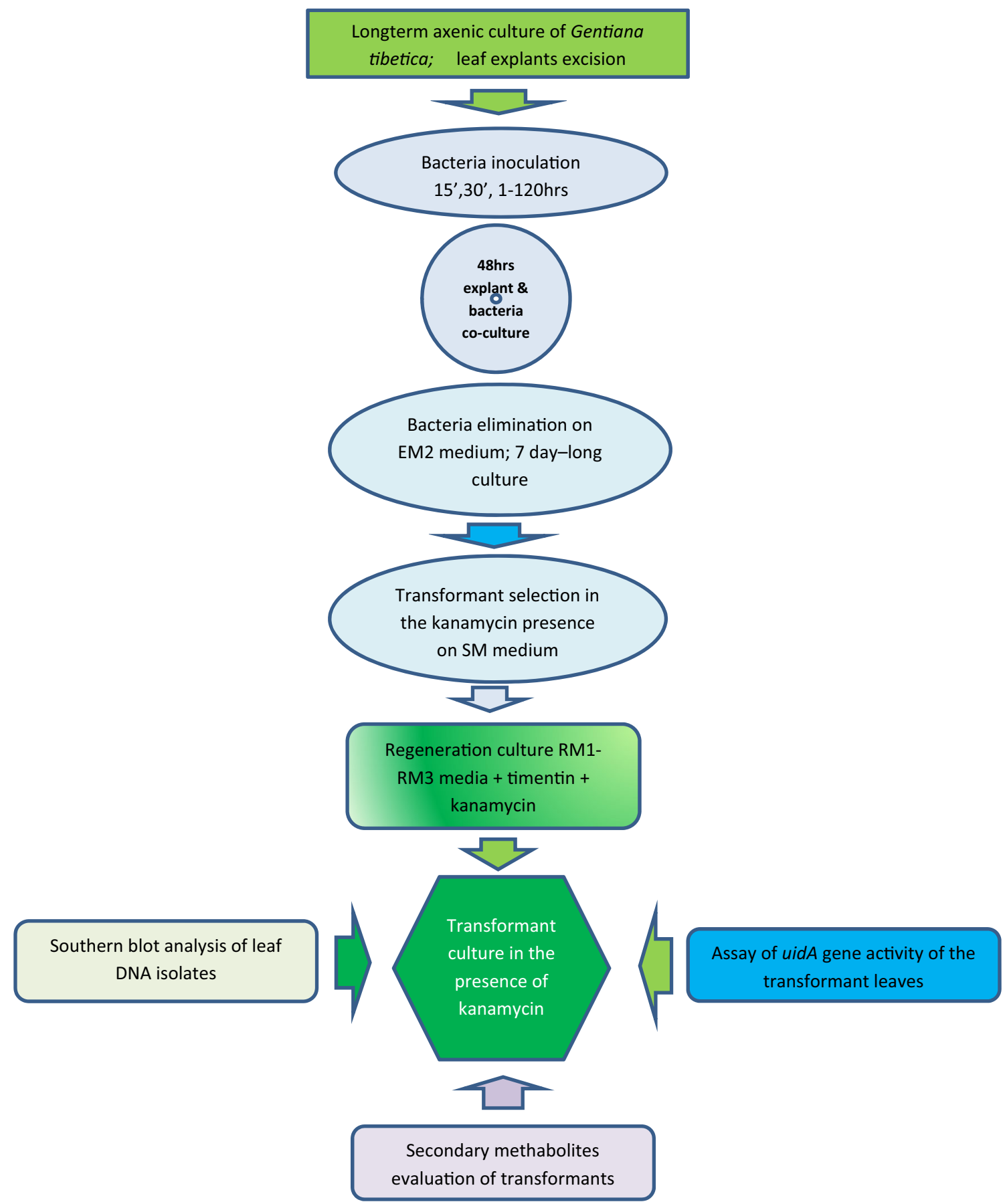

Fig. 1 Diagram of procedure involved in vector transformation of G. tibetica leaf explants derived from axenic culture carried on hormone-free MS medium 
Table 1 Media used for establishment elimination of Agrobacterium tumefaciens, selection, and regeneration of transformed material

\begin{tabular}{|c|c|c|}
\hline $\begin{array}{l}\text { Name of } \\
\text { medium }\end{array}$ & Content & Medium application \\
\hline KSCM1 & $\begin{array}{l}\mathrm{MS}+1.0 \mathrm{mg} / \mathrm{l} \mathrm{NAA}+0.25 \mathrm{mg} / \mathrm{l} \mathrm{KIN}+30 \mathrm{~g} / \mathrm{l} \\
\text { sucrose }+ \text { agar }+0 ; 25 ; 50 ; 75 ; 100 \mathrm{mg} / \mathrm{K} \mathrm{KAN}\end{array}$ & $\begin{array}{l}\text { Media used for evaluation of kanamycin concentration for uid gene } \\
\text { transformants selection }\end{array}$ \\
\hline KSCM2 & $\begin{array}{l}\mathrm{MS}+2.0 \mathrm{mg} / \mathrm{l} \mathrm{NAA}+1.0 \mathrm{mg} / \mathrm{l} \mathrm{CPPU}+30 \mathrm{~g} / 1 \\
\text { sucrose }+ \text { agar }+0 ; 25 ; 50 ; 75 ; 100 \mathrm{mg} / \mathrm{KAN}\end{array}$ & \\
\hline AIM1 & $\begin{array}{l}\text { MS }+30 \mathrm{~g} / \mathrm{l} \text { sacharozy }+ \text { agar }+0 ; 100 ; 150 ; 200 \\
250 ; 300 \mathrm{mg} / \mathrm{l} \mathrm{CEF} \text { either TIM }\end{array}$ & $\begin{array}{l}\text { Media used of timentin and cefatoxime concentration evaluation on the } \\
\text { effect on morphogenic potential of leaf explants }\end{array}$ \\
\hline AIM2 & $\begin{array}{l}\mathrm{MS}+2.0 \mathrm{mg} / \mathrm{l} \mathrm{NAA}+1.0 \mathrm{mg} / \mathrm{l} \mathrm{CPPU}+30 \mathrm{~g} / \mathrm{l} \\
\text { sacharozy }+ \text { agar }+0 ; 100 ; 150 ; 200 ; 250 \\
300 \mathrm{mg} / \mathrm{l} \mathrm{CEF} \text { either TIM }\end{array}$ & \\
\hline IM1 & $\mathrm{MS}+\mathrm{ACET}$ & Incubation of leaf blade explants in bacterium suspension \\
\hline $\mathrm{CM} 3$ & $\mathrm{MS}+30 \mathrm{~g} / \mathrm{l}$ sucrose + agar & Co-culture of leaf blade explants with bacterium \\
\hline EM3 & $\mathrm{MS}+30 \mathrm{~g} / \mathrm{l}$ sucrose $+\mathrm{TIM}+$ agar & Medium for bacteria elimination from tissue of explants \\
\hline SM5 & $\mathrm{MS}+30 \mathrm{~g} / \mathrm{l}$ sucrose $+\mathrm{TIM}+\mathrm{KAN}+$ agar & Medium used for selection of transformed material carrying $n p t I I$ gene \\
\hline RM1 & $\begin{array}{l}\mathrm{MS}+1.0 \mathrm{mg} / \mathrm{l} \mathrm{KIN}+0.5 \mathrm{mg} / \mathrm{l} \mathrm{GA}{ }_{3}+80 \mathrm{mgt} / \mathrm{l} \\
\mathrm{SA}+30 \mathrm{~g} / \mathrm{l} \text { Sucrose }+\mathrm{KAN}+\text { agar }\end{array}$ & $\begin{array}{l}\text { Media used for plant regeneration from leaf explants transformed by } A \text {. } \\
\text { tumefaciens strain } \mathrm{C} 58 \mathrm{C} 1\end{array}$ \\
\hline RM2 & $\begin{array}{l}\mathrm{MS}+1.0 \mathrm{mg} / \mathrm{l} \mathrm{KIN}+0.5 \mathrm{mg} / \mathrm{l} 2,4-\mathrm{D}+30 \mathrm{~g} / \mathrm{l} \\
\text { Sucrose + KAN + agar }\end{array}$ & \\
\hline RM3 & WPM $+30 \mathrm{~g} / \mathrm{l}$ Sucrose + KAN + agar5 & \\
\hline
\end{tabular}

\section{Agrobacterium tumefaciens culture}

The culture of A. tumefaciens was held on an agar medium at $+4{ }^{\circ} \mathrm{C}$, when stored for long time, bacteria were immersed in glycerol and kept at $-80{ }^{\circ} \mathrm{C}$.

Agrobacterium tumefaciens cells carrying pDraGONG:GFP was constructed on the basis of pCB 301 plasmid having in the region of T-DNA GUS int and $g f p$ genes under $35 \mathrm{~S}$ promoter of cauliflower mosaic virus, and nptII gene under napolin promoter. The bacteria were additionally supplemented by plasmid pCH32 (helper plasmid containing $\operatorname{vir} G$ and $\operatorname{virE}$ genes). The bacteria cultures were maintained on a YEB agar medium (5.0 g/l Peptone, $5.0 \mathrm{~g} /$ 1 Yeast extract, $1.0 \mathrm{~g} / \mathrm{l}$ Beef extract, $0.49 \mathrm{~g} / \mathrm{MgSO}_{4}$ with or without $15 \mathrm{~g} / \mathrm{l}$ Agar, $\mathrm{pH}$ 7.2) and before the experiments were commenced, 2-day fresh subculture was done. From this culture, individual bacteria colonies were transferred to a fresh liquid YEB medium for multiplication. These cultures were maintained during $24 \mathrm{~h}$ in the dark at $28{ }^{\circ} \mathrm{C}$ on a rotary shaker with $180 \mathrm{rpm}$. Just before the experiment, the bacteria were collected and washed three times using sterile $10 \mathrm{mM} \mathrm{MgSO}$. Finally, the bacteria pellet was transferred into an inoculation medium IMI with $\mathrm{OD}=0.8$ at $\lambda=600 \mathrm{~nm}$. Table 1 presents the media used in the Agrobacterium transformation procedure.

\section{Bacteria inoculation and co-culture}

Freshly excised leaf explants (totally in all experiments 11,700 pieces) originated from axenic culture were immersed in the bacteria suspension in IM1 medium (immersion medium). Medium was dispersed into petri dishes and inoculation was carried out during the following periods of time: 15 or $30 \mathrm{~min}$, and 1, 2, 4, 24, 48, 72 , and $120 \mathrm{~h}$ at $25{ }^{\circ} \mathrm{C}$ in the darkness in the presence of L-glutamine. Later, an explants were washed by three time immersion in sterile distilled water supplemented with $150 \mathrm{mg} / \mathrm{l}$ of timentin, dried, and transferred on the Whattman paper no. 3 located over CM4 agar medium (co-culture medium) for $48 \mathrm{~h}$. After that time, plant material was implanted on the surface of agar EM2 medium (bacteria elimination medium) devoted to bacteria elimination, and next 7 days, explants were maintained on selection agar SM3 medium (selection medium) supplemented with kanamycin at the presence of timentin. 

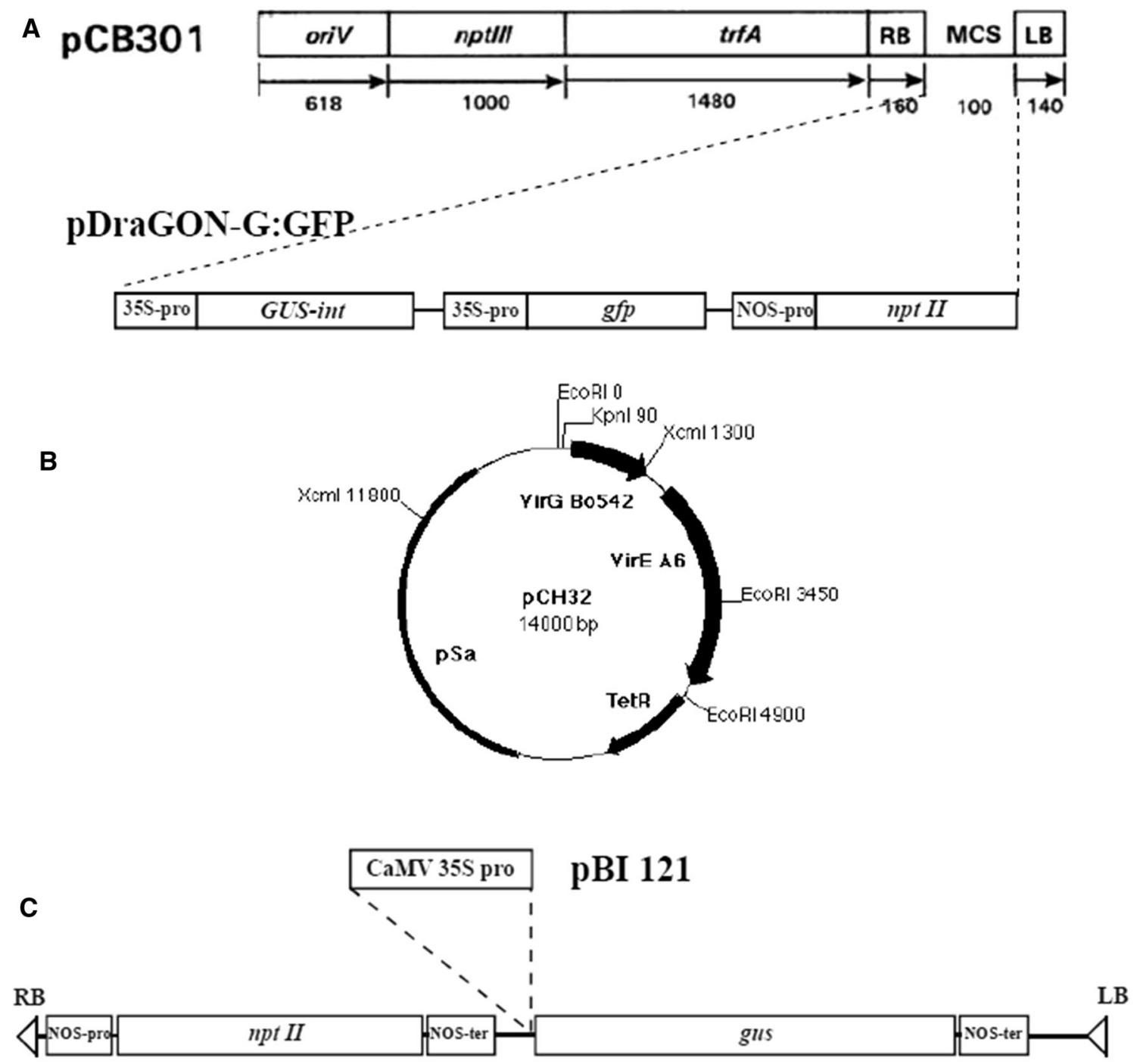

\section{pBI 101}

Map of plasmids.

A. pCB301 (Xiang et al. 1999) and vector pDraGON$\mathrm{G}: \mathrm{GFP}$,

B. Helper plasmid pCH (Hamilton 1997) acc. http://www. biotech.cornell.edu,

C. Fragment of T-DNA plasmid pBI 121 (Jefferson et al. 1987).

(RB/LB left/right border, MCS polylinker (multiple cloning site), gus- $\beta$-glucuronidase coding gene. npII and npIII-neomycine phosphotransferase coding genes (kanamycin resistance), gfp-green fluorescence protein coding gene, 35S-pro (CaMV $35 \mathrm{~S}$ pro)-Cauliflower Mosaic Virus promotor, NOS-pro/NOS-ter-promoter/ terminator of nopalin synthase gene, oriV and $\operatorname{trf} A-$ part of ori replication of $\mathrm{RK} 2$ plasmid, $\mathrm{pSa}$ - ori replication of PSa plasmid, Tet ${ }^{\mathrm{R}}$-resistance for tetracycline, vir $V$ and vir $G$ genes-Agrobacterium genes responsible for protein coding connected with vir activation and T-DNA transfer).

\section{The effect of L-glutamine on transformation} efficiency

To describe the role of the L-glutamine in transformation experiment, the following concentration ranged from 0.0 to $2.0 \mathrm{~g} / \mathrm{l}$ was employed. Time of an explant treatment was correlated with the time of incubation of plant material with bacterium. IM1 medium was supplemented with filter (Sartorius pore size $02 \mu \mathrm{m}$ ) sterilized L-glutamine. 


\section{Transformant regeneration}

After 7-day-long selection, culture explants were transferred on three regeneration media RM1, RM2, and RM3 media which differ in mineral salts content and PGR concentration supplemented with timentin at the presence of kanamycin. Finally, transformants were cultured in glass jars containing TPM medium supplemented with kanamycin (Table 1).

\section{Assay of GUS activity}

The GUS transient and in transformants uidA gen expression was assayed with 5-bromo-4-chloro-3-indolylglucuronide (X-Gluc) as a substrate. Tissues were incubated in the reaction mixture, including $1.0 \mathrm{mM} \mathrm{X}$-Gluc in DMSO, $20.0 \mathrm{mM}$ phosphate buffer $\mathrm{pH}=7.0,0.25 \mathrm{mM}$ Triton $\mathrm{X}-100$, and $3.12 \mathrm{mM}$ methanol. In the reaction mixture, the plant material was left for $24 \mathrm{~h}$ at temperature $37^{\circ} \mathrm{C}$ in the dark. After that, three washes with $70 \%$ ethanol helped to extract chlorophyll from tissues to show blue (dichlorodibromoindigo) coloration of GUS reaction. Finally, the tissues were fixed with Carnoy'a fixative (acetic acid:ethanol in proportion 1:3).

\section{PCR analysis of transgenesis}

To confirm transgenesis, one pair of primers for marker nptII gene (selection gene) and one pair of primers for uid $A$ gene (reporter gene) were used for testing. For PCR reaction, the following starters have been applied for $n p t ~ I I$ gene first- $\left(5^{\prime}\right.$-GAGGCTATTCGGCTATGACTG- $\left.3^{\prime}\right)$ and second (5'-ATCGGGAGCGGCGATACCGTA- $\left.3^{\prime}\right)$ with amplification of $700 \mathrm{bp}$ fragment (Dong and McHughen 1993). Following thermal profile was adopted: pre-denaturation at $95{ }^{\circ} \mathrm{C} 15 \mathrm{~min}, 30$ cycles of denaturation $94{ }^{\circ} \mathrm{C}$ $30 \mathrm{~s}$, annealing at $56{ }^{\circ} \mathrm{C} 30 \mathrm{~s}$, and synthesis at $72{ }^{\circ} \mathrm{C} 60 \mathrm{~s}$. It was followed by final extension $72{ }^{\circ} \mathrm{C} 5 \mathrm{~min}$ and pause at $4{ }^{\circ} \mathrm{C}$. For uid $A$ gene, following starters were tested: $1-$ $\left(5^{\prime}\right.$-TTATCTCTATGAACTGTGCGTCA- $\left.3^{\prime}\right)$ and $2-\left(5^{\prime}-\right.$ TTGGACATACCATCCGTAATAA-3') with amplification of $679 \mathrm{bp}$. Fragments Primers were designed according to the Primer3 program on the basis of uidA gene sequences found in data base NCBI (2008a). Following thermal profile was adopted: pre-denaturation at $95{ }^{\circ} \mathrm{C}$ $15 \mathrm{~min}, 30$ cycles of denaturation $94{ }^{\circ} \mathrm{C} 30 \mathrm{~s}$, annealing at $51{ }^{\circ} \mathrm{C} 1 \mathrm{~min}$, and synthesis at $72{ }^{\circ} \mathrm{C} 2 \mathrm{~min}$. It was followed by final extension $72{ }^{\circ} \mathrm{C} 10 \mathrm{~min}$ and pause at $4{ }^{\circ} \mathrm{C}$.

\section{Southern blot analysis of transgenic regenerants}

An analysis was carried out for two fragments of genes nptII and uidA. Isolated DNA from randomly selected plants, the transgenic character of which was early confirmed with the help of a PCR analysis, underwent Southern blot hybridization. DNA of non-transformed, wild type of plants constituted negative control. DNA plasmid isolated from strain C58CI of A. tumefaciens was positive control. Each DNA sample was digested by EcoRI/Bam HI $65 \mu \mathrm{l}$ reaction mixture contained $10 \mu \mathrm{g}$ DNA (diluted in $30 \mu 1 \mathrm{H}_{2} \mathrm{O}$ ), $1 \times$ NEBuffer $3+$ one of the studied restriction enzyme. The sample was supplemented with 200u of enzymes of BamHI and EcoRI (New England Biolabs). The digestion was carried out at temperature $37{ }^{\circ} \mathrm{C}$ during about $24 \mathrm{~h}$. Digested DNA was separated on $0.9 \%$ agarose gel in $1 \times$ TEB buffer at the presence of voltage; $7 \mathrm{~V} / \mathrm{cm}$ during $5 \mathrm{~h}$. Later, sample was transferred on the nitrocellulose filter and the hybridization was made according Sambrook et al. (1989).

\section{Gentiopicrosides evaluation of transformants and their wild forms}

The gentiopicroside content was evaluated on the basis of the external standard of a methanol solution of gentiopicroside (Chromadex) at a concentration of $0.2 \mathrm{mg} / \mathrm{ml}$.

Twelve randomly selected transformants T0 of $G$. tibetica together with wild form of G. criciata, G kurroo, and $G$. lutea derived from field and axenic cultures were considered for the gentiopicroside content evaluation. After collection, all samples of plant material were directly freeze-drying. Three hundred milligram samples were taken for hot methanol extraction. After that, samples were evaporated and diluted in $5 \mathrm{ml}$ of $30 \%$ methanol and analyzed with the help of HPLC (High-Performance Liquid Chromatography). Column Lichrospher 100 RP18 $(250.0 \times 4.0 \mathrm{~mm}, 5.0 \mu \mathrm{m})$, flow $1.10 \mathrm{ml} / \mathrm{min}$, column temperature $40{ }^{\circ} \mathrm{C}$, and schema of elucidation included $0.0-60$ min with $90 \% \mathrm{~A}+10 \% \mathrm{~B}$ up to $90 \% \mathrm{~A}+10 \% \mathrm{~B}$ when $\mathrm{H}_{3} \mathrm{PO}_{4}$ aq (A) and Acetonitryl (B) formed moving faze created conditions of the analysis.

\section{Statistical analysis}

A statistical analysis was performed with the application of the Statgraphics Plus4.1 program. The number of samples and their size, and the number of experiment repetition have been presented together with experiment description.

\section{Results}

Leaf explant response to $\beta$-lactam antibiotics (timentin and cefotaxime)

The leaf anatomy helps the bacteria to penetrate the blade interior via stomata. The treatment of such explants with the 
$\beta$-lactam antibiotics results to get rid of the bacterium from explants in a post-transformation culture. In our experiments, two of the $\beta$-lactam antibiotics were used: timentin and cefatoxime in concentrations from 0.0 to $300 \mathrm{mg} / \mathrm{l}$ in the presence of hormone-free medium (AIM1), or alternatively with NAA and CPPU in solidified medium (AIM2).

The presence of antibiotics in a hormone-free medium resulted in a very insignificant morphogenic response of explants or, alternatively, in their death. A higher percentage of dying explants occurred in the presence of cefatoxime. In the presence of plant growth hormones, the lack of timentin effects on callus proliferation was noted. A lower number of responding explants were observed when the medium was supplemented with cefatoxime; however, the percentage was higher than $80 \%$. Callus proliferation occurred on the cut surface of the explants and the callus presented a certain level of hydration and a green-yellow color. The most significant difference in the response of the explant was observed in the highest concentrations of the used antibiotic $(300 \mathrm{mg} / \mathrm{l})$. The presence of cefatoxime resulted in the regeneration of a small amount of callus which quite early got brown with signs of death. However, the effect of timentin was completely opposite, expressing a yellow-golden callus proliferation without any sign of suppression of the morphogenic character of the culture.

Among the studied A. tumefaciens strains LBA 4404(1) and LBA 4404(2) (data not shown), only C58C1 strains appeared to be a successful vector for the transformation of G. tibetica leaf explants. For improving the efficiency of transformation, various concentrations and durations of $\mathrm{L}^{-}$ glutamine treatment were used. After inoculation, the explants were transferred to CM3 medium for co-culture and EM3 medium with timentin for bacteria elimination. In the presence of an SM5 medium supplemented with kanamycin (selection agent), the selection took place and not transformed cells were eliminated as the result of their response on $50 \mathrm{mg} / \mathrm{l}$ of antibiotics. After that, the following RM1, RM2, and RM3 media, supplemented with various PGRs, appeared a new environmental culture conditions to stimulate the regeneration processes. To describe the whole procedure and its expression in particular stages of transformant regeneration, the uid gene expression was explored. The blue color, being a tool of the visualization of a chemical reaction of the uid gene products with X-gluc substrate, helps to evaluate the efficiency of the transformation. The following periods of post-transformation culture were explored: 7 days, and 6 and 16 weeks for the evaluation of the transgenesis.

\section{L-Glutamine effect on the transformation efficiency}

The efficiency of transgenesis, studied after 7 days of culture, indicated an immediate relation between the used Lglutamine concentration and the time of explant incubation. The percentage of transformed explants increased together with the rising concentration of L-glutamine and extension of its incubation time. Two factorial variance analyses indicated a statistically significant effect of the concentration and time of incubation of L-glutamine on the transformation efficiency. The synergy of both studied factors, likewise, significantly affected the obtained results. Only in the case of experiments carried out during 24-120 h, no statistically significant relation between the time of incubation and Lglutamine concentration and the affectivity of transformation was noted. Independently of L-glutamine concentrations, explants incubated from 24 to $120 \mathrm{~h}$ presented a positive GUS reaction. However, incubation longer than $24 \mathrm{~h}$ resulted in the decay of the result because of the negative influence of bacteria on the living plant tissue. In the case of a shorter incubation time, for example from $15 \mathrm{~min}$ to $4 \mathrm{~h}$, the interdependence of L-glutamine concentration and the efficiency of the process were observed. With a rising concentration of L-glutamine, the efficiency of the transformation increased. This phenomenon occurred particularly in the 15th min of the incubation time. Explants incubated during $120 \mathrm{~h}$ in the presence of $2.0 \mathrm{~g} / \mathrm{l} \mathrm{L}$-glutamine showed $30 \%$ of $\beta$-glucuronidase activity. However, in such a case, the standard error was very high (Fig. 2).
Fig. 2 Transformation efficiency of leaf explants of $G$. tibetica expressed by the $\beta$ glucuronidase activity after 7 days of transformation experiment (the data label with the same letter are not significantly different; $p>0.05)$

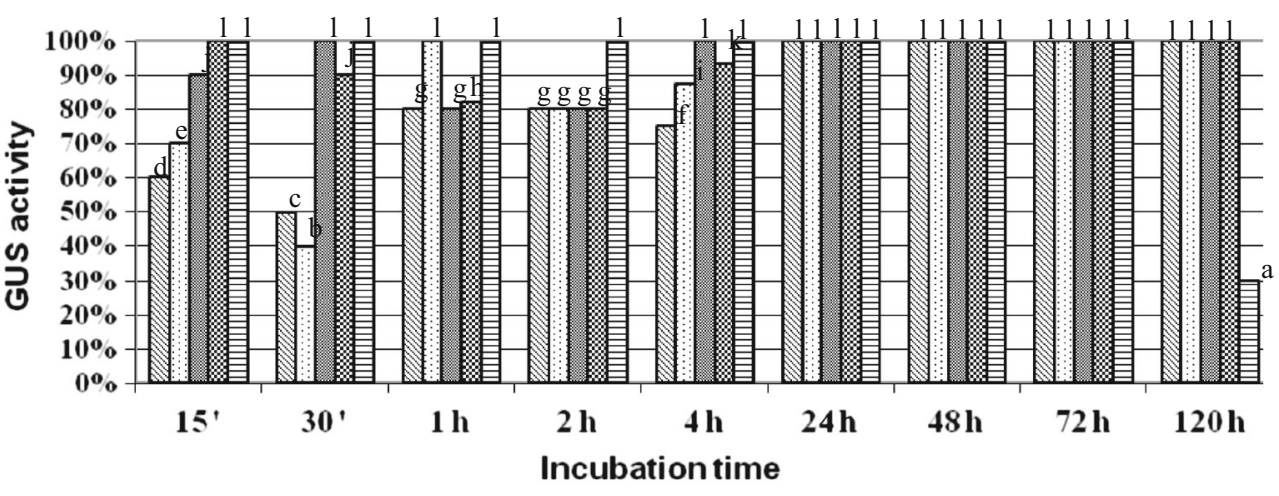

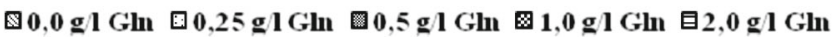


Besides of the intensity of blue colorization of the leaf explant, the area of the responding explant showing gus gene expression could be selected as the second factor of transformation evaluation. The surface of leaf explants with expression of reporter gene $\beta$-glucuronidase was different in relation to the arranged variance of experiments. The explant incubation with Agrobacterium for $15 \mathrm{~min}$ to $4 \mathrm{~h}$ afforded possibilities of blue colorization of only fragments of explants and not stained cells were present next to blue stained fragments.

The time extension of the inoculation resulted in the increase of the area of leaf blade showing expression of $\beta$-glucuronidase. Explants incubated longer than $24 \mathrm{~h}$ were completely blue stained. The intensity of $\beta$-glucuronidase activity was affected by the L-glutamine concentration in the inoculation medium. Together with the increasing L-glutamine concentration, the blue staining intensity was highly colored. The lack of L-glutamine resulted in individual stained regions of the explant, while in its presence, the area and intensity of stained tissue significantly increased. The presence of the highest concentration-2.0 g/l L-glutamine-resulted in total blue staining of explants as a result of uid gene expression (Fig. 3).

\section{Morphogenic events in transgenesis}

For the evaluation of transformation, morphogenic response of transformed explant is the most important. In this field, the first response consisted on the callus formation that mostly happened on the open cut surface of the explant. Explants incubated with bacteria longer than $24 \mathrm{~h}$ did not form a callus tissue, and in the majority of cases, they gradually died. The lack of L-glutamine in the medium stimulated the non-formation of the callus. The highest yielding of callus (87.5\% of explants) was observed when cultures were incubated during $30 \mathrm{~min}$ in the presence of $2.0 \mathrm{~g} / \mathrm{l}$ of L-glutamine (Table 2). The initial response of explants occurred after 3 weeks of co-culture. The emerging callus had the following characteristics; its structure was compact and granular with a variation of colors, from yellow to deep green. No differences were observed of the responding explants regardless of the content of PGR in media used for regeneration (media RM1-RM3) (Table 1). Both factors, L-glutamine and its concentration, as well as the length of the incubation time had statistically significant influence on the efficiency of a transgenic callus formation. In addition, a significant joint action of both factors mentioned above was shown.

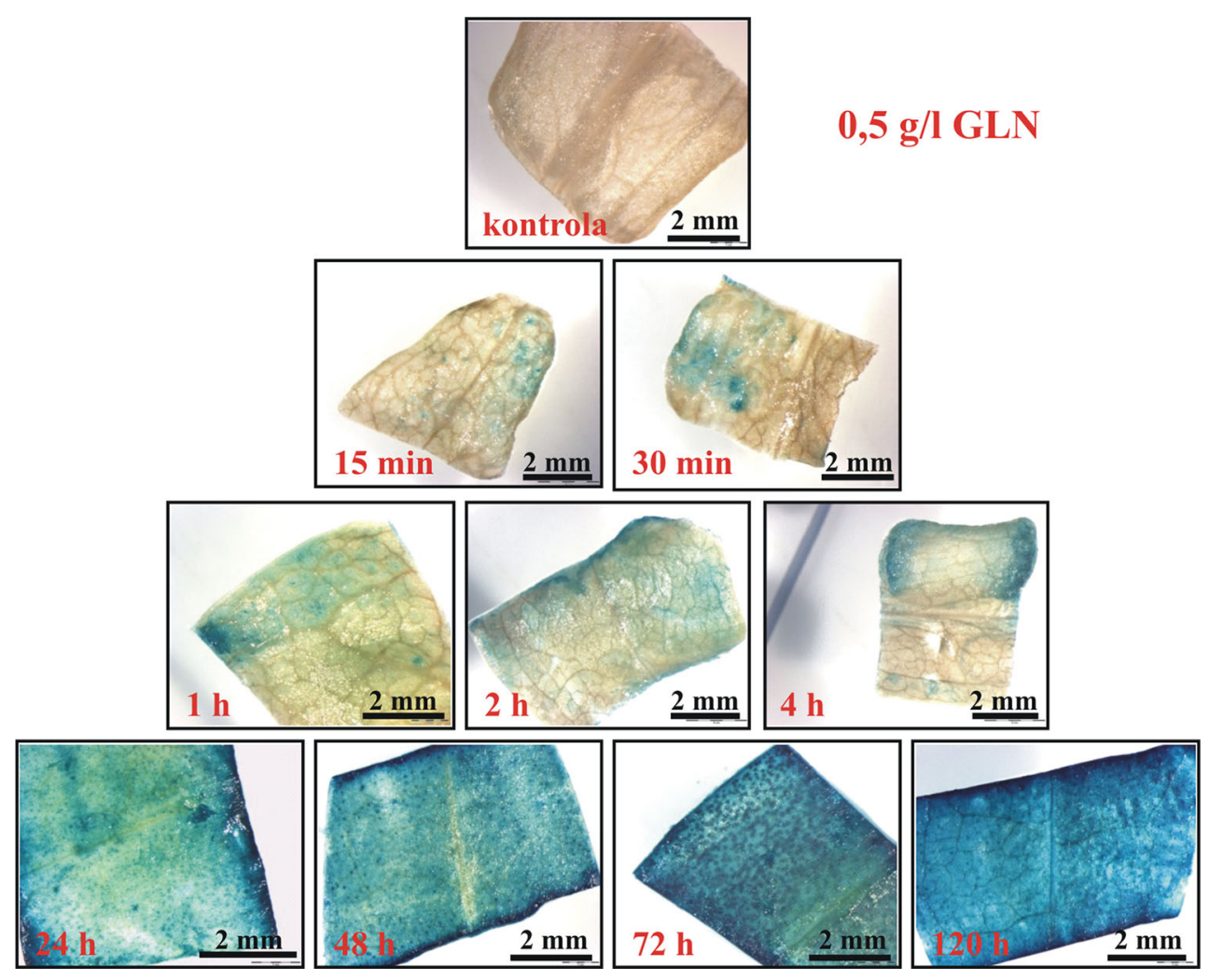

Fig. 3 Histochemical reaction of GUS observed on leaf explants of G. tibetica after transformation using strain $\mathrm{C} 58 \mathrm{C} 1 \mathrm{~A}$. tumefaciens in the presence of $0.5 \mathrm{~g} / \mathrm{l} \mathrm{L}$-glutamine and incubation from $15 \mathrm{~min}$ to
120 h. Together with the time of incubation, the blue staining was more intensive and the surface of explant expressing blue color increased 
Table 2 Number of transgenic callus lines of $G$. tibetica obtained on the leaf explants assessed with the help the activity of $\beta$-glucuronidase gene in relation to the total number of scored callus tissue

\begin{tabular}{lllllll}
\hline \multirow{2}{*}{ Time of incubation } & \multicolumn{6}{l}{ L-Glutamine concentration $(\mathrm{g} / \mathrm{L})$} \\
\cline { 2 - 6 } & 0.0 & 0.25 & 0.5 & 1.0 & 2.0 & $\sum$ \\
\hline $15 \mathrm{~min}$ & 0 & $18 / 25^{\mathrm{j}}$ & $30 / 32^{\mathrm{o}}$ & $36 / 39^{\mathrm{p}}$ & $25 / 25^{\mathrm{k}}$ & $109 / 121$ \\
$30 \mathrm{~min}$ & 0 & $22 / 30^{\mathrm{m}}$ & $32 / 35^{\mathrm{t}}$ & $44 / 46^{\mathrm{s}}$ & $175 / 179^{\mathrm{d}}$ & $273 / 290$ \\
$1 \mathrm{~h}$ & 0 & $33 / 33^{\mathrm{n}}$ & $37 / 38^{\mathrm{w}}$ & $56 / 57^{\mathrm{u}}$ & $145 / 145^{\mathrm{c}}$ & $271 / 273$ \\
$2 \mathrm{~h}$ & 0 & $40 / 40^{\mathrm{i}}$ & $39 / 39^{\mathrm{r}}$ & $112 / 113^{\mathrm{l}}$ & $139 / 140^{\mathrm{b}}$ & $330 / 332$ \\
$4 \mathrm{~h}$ & 0 & $41 / 41^{\mathrm{e}}$ & $61 / 61^{\mathrm{g}}$ & $140 / 141^{\mathrm{f}}$ & $25 / 25^{\mathrm{h}}$ & $267 / 268$ \\
$24 \mathrm{~h}$ & - & - & - & - & - & - \\
$\sum$ & & $154 / 169$ & $199 / 205$ & $388 / 396$ & $509 / 514$ & $1250 / 1284$ \\
\hline
\end{tabular}

Values described by the same letters are not significantly various $(p>0.05)$
Fig. 4 Exploded-piechart showing the percentage of transgenic plantlet regeneration on leaf explants of G. tibetica after co-culture of $A$. tumefaciens strain $\mathrm{C} 58 \mathrm{C} 1$ at the presence of increasing Lglutamine concentration

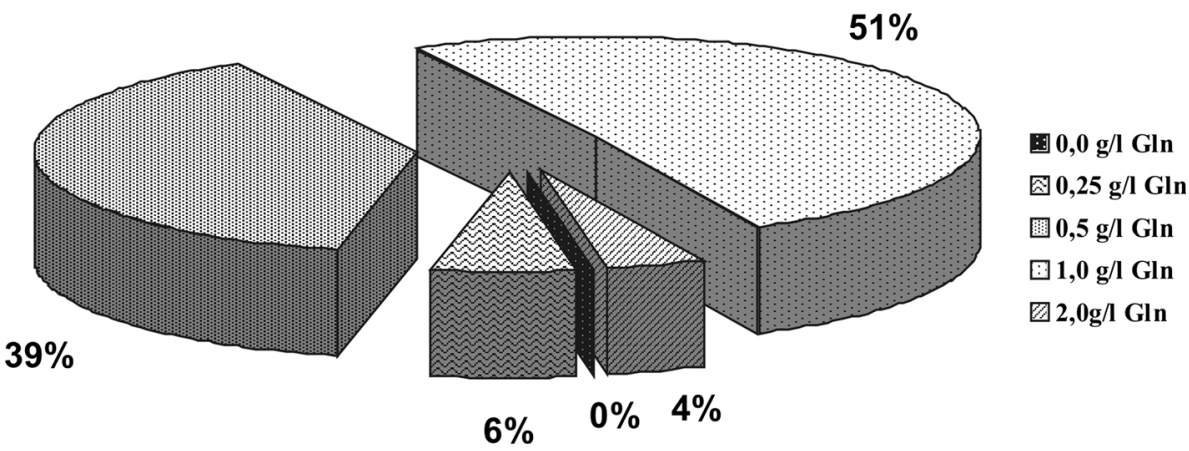

Considering the activity of glucuronidase as the factor describing the efficiency of transformation, the lowest results were obtained in the case of $0.25 \mathrm{~g} / \mathrm{l}$ of L-glutamine with a shorter time of incubation 15 min (Table 2).

After 8 weeks of post-transformation culture, the first symptoms of plant regeneration on the transgenic tissue were recognized. Even though the post-transformation culture was carried out in the presence of an optimal concentration of the selection agent-kanamycin, 7 out of 203 totally regenerated plants did not show transgenesis (lack of positive GUS reaction). The intensity of transformant regeneration was strongly depending on three agents: the incubation time, the concentration of L-glutamine, and the regeneration medium (Fig. 4). The most effective regeneration occurred on explants transformed in the presence of 0.5 and $1.0 \mathrm{mg} / \mathrm{l}$ of L-glutamine during 30 or $60 \mathrm{~min}$ of the bacterial incubation. Both the extension of incubation time for over $1 \mathrm{~h}$ and the increase in L-glutamine concentration higher than $1.0 \mathrm{~g} / \mathrm{l}$ resulted in a significant reduction of the regeneration activity of the culture. Comparing the number of regenerated transformants to the number of transformed explants, the highest yield occurred in a combination of $1.0 \mathrm{~g} / \mathrm{l} \mathrm{L}$-glutamine and $1 \mathrm{~h}$ of the incubation $(22.5 \%)$. The increase in both, L-glutamine concentration and the time of incubation, resulted in a drastic reduction of the culture efficiency. The significance of the application of L-glutamine in incubation is shown in Fig. 6, indicating that 51 and $39 \%$ of obtained transformats were obtained in the presence of $1.0 \mathrm{~g} / \mathrm{l}$ and $0.5 \mathrm{~g} / \mathrm{l} \mathrm{L}$-glutamine, respectively. The application of a lower or higher concentration of that amino acid resulted in a very drastic reduction of the regeneration activity. The most conductive time of regeneration appeared $1 \mathrm{~h}$ after incubation, reaching $43 \%$ of all transgenic plant lines. The extension and shortening of the incubation time resulted in the reduction of the transformant regeneration (Fig. 5). The regeneration occurred on three studied regeneration media (RM1-RM3). The most effective, however, appeared the hormone-free medium (RM3) with $72 \%$ of the total number of transformants (Fig. 6). The medium supplemented with $\mathrm{GA}_{3}+$ kinetin and AS (RM1) created the most uncomfortable regeneration conditions (5\%).

\section{Molecular analysis of transformants}

\section{PCR analysis}

For the PCR optimization conditions, and the amplification of nptII, uid A, and vir $G$ genes, DNA fragments of the plasmid of the strain C58C1 A. tumefaciens were explored. Two pairs of primers for $\operatorname{vir} G$ were tested. Only the second pair of tested primers ( $5^{\prime}$-CTGGCGGCAAAGTC TGAT$3^{\prime}, 5^{\prime}$-TGTCGTAAACCTCCTCGT- $\left.3^{\prime}\right)$ allowed the amplification of an expected fragment (450 bp) of vir $G$. On the basis of the reaction that was carried out for temperature 
Fig. 5 Exploded-pie-

chart presenting the percentage of transgenic plantlet regeneration of $G$. tibetica on leaf explants transformed with strain $\mathrm{C} 58 \mathrm{C} 1 \mathrm{~A}$. tumefaciens in correlation to time of the bacterial suspension incubation

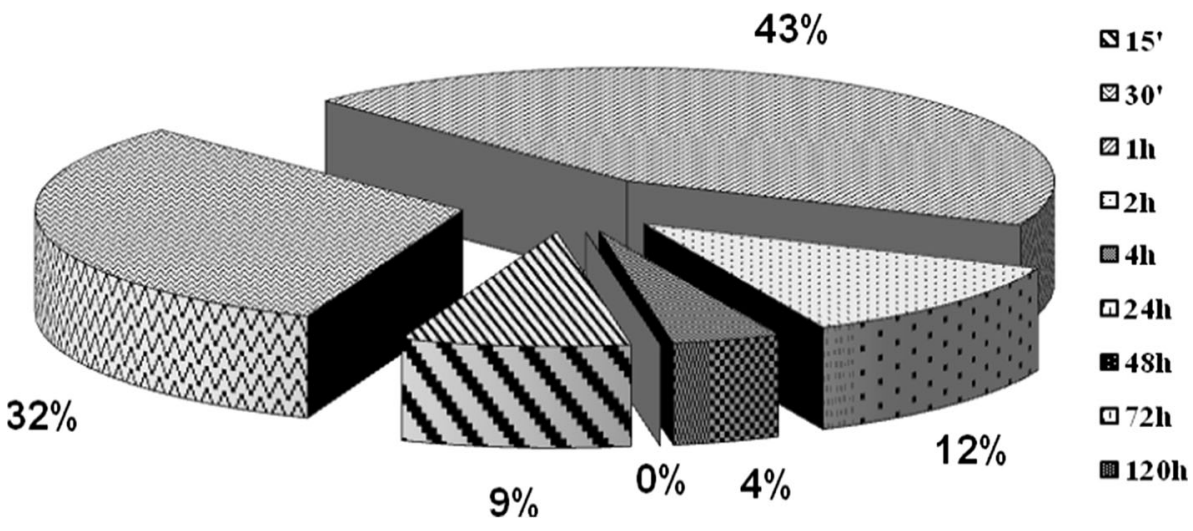

Fig. 6 Regeneration of transgenic plantlets and $\beta$ glucuronidase activity expression (blue color) in $G$. tibetica cultures in the presence of $50 \mathrm{mg} / \mathrm{l} \mathrm{kanamycin.} \mathrm{a} \mathrm{Initial}$ stage of transformant shoot regeneration, b 6-month-old transgenic regenerants cultured on hormone-free MS medium, c 6-week-old transgenic plantlet expressing uidA gene, and $\mathbf{d}$ leaf totally expressing uidA gene originated from 6-month-old transformant
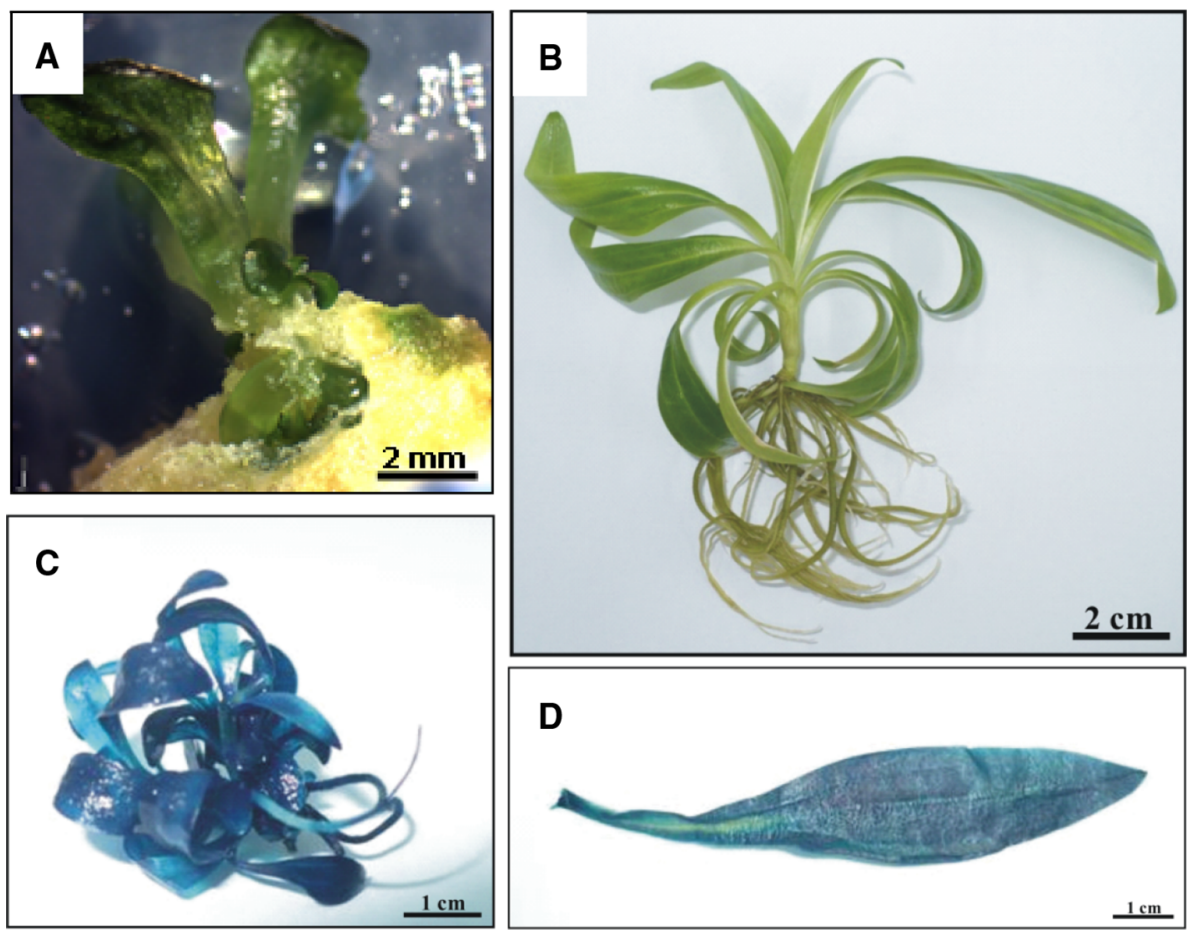

evaluation for further experiments, $54{ }^{\circ} \mathrm{C}$ has been selected.

For nptII gene, only one pair of starters was tested $5^{\prime}$ GAGGCTATTCGGCTATGACTG-3', 5'-ATCGGGAGC GGCGATACCGTA-3'. Electrophoresis allowed to show up the set of bends of the expected size $700 \mathrm{bp}$. Among six temperature gradients analyzed, only $54{ }^{\circ} \mathrm{C}$ was chosen for further experiments.

Two pairs of primers were tested for uid A gene. Both pairs allowed amplification of fragments of genes. Starters $5^{\prime}$-CTGATAGCGCGTGACAAAAA- $3^{\prime}$ and 5'-GGCACAGCACATCAAAGAGA- $3^{\prime}$ (the first pair) allowed amplification of $208 \mathrm{bp}$ fragment of gene. The reaction was carried out with six temperature gradients of amplification. Each of the temperatures allowed to have a DNA fragment of an expected number of pair base amplified.
The primers $5^{\prime}$-TTATCTCTATGAACTGTGCGTCA-3' and 5'-TTGGACATACCATCCGTAATA-3' (II pair) allowed to have amplification of 679 bp 4 fragments of the gene. The temperature of the starter amplification was settled down at $51{ }^{\circ} \mathrm{C}$. For further experiments, the second pair of starters was selected.

\section{Analyses of transgenic regenerants}

PCR DNA analysis of 196 transformats of $G$. tibetica showing $\beta$-glucuronidase activity obtained from transformed leaf explants confirmed the presence of $n p t I I$ and uidA genes (Figs. 6, 7, 8). Out of all studied regenerants, only three showed the band of $450 \mathrm{bp}$ which confirmed Agrobacterium contamination. That regenerants were not considered for further analysis. 
Fig. 7 PCR analysis of gene expression of eleven free

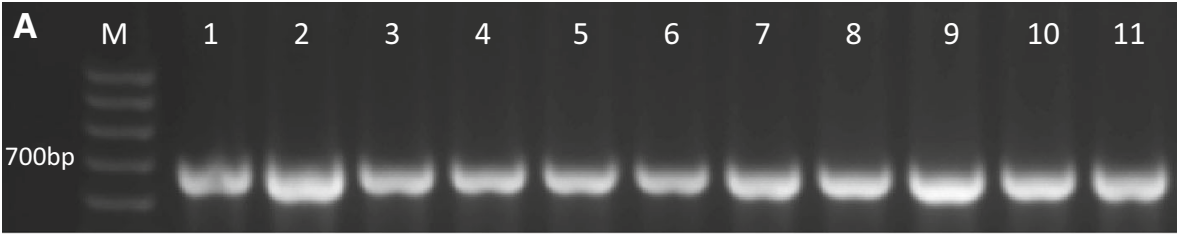
transformants. a uidA (679 bp), b $\operatorname{nptII}(700 \mathrm{bp})$

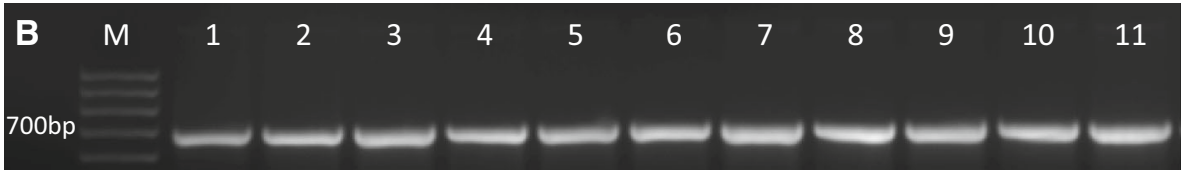

A

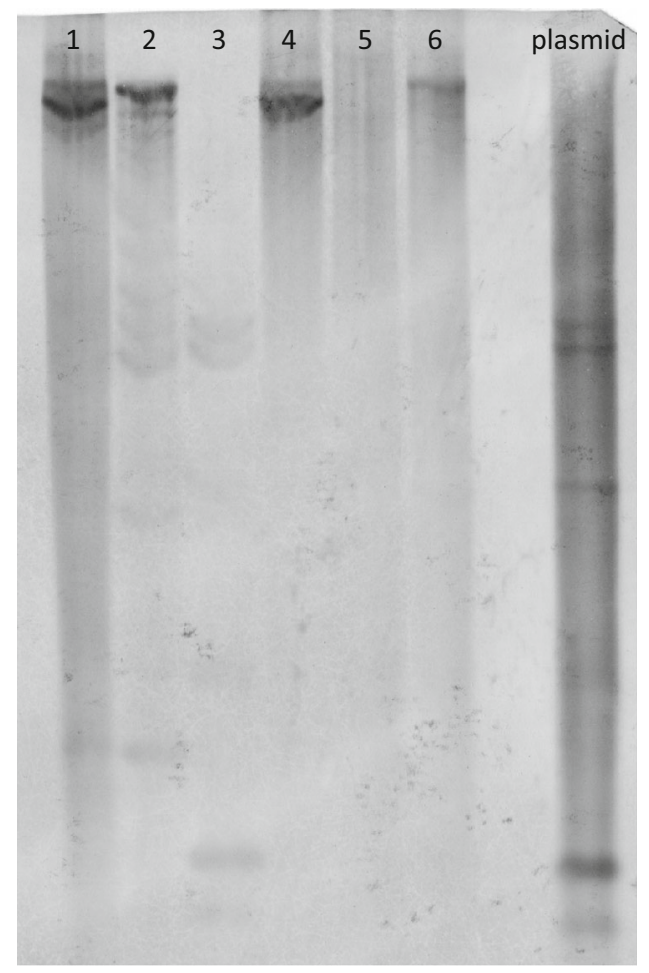

Fig. 8 Southern blot analysis of five free selected $G$. tibetica transformants confirms the presence of the nptII and uidA genes. Each DNA sample was digested by EcoRI/BamHI. $65 \mu 1$ reaction mixture contained $10 \mu \mathrm{g}$ DNA (diluted in $30 \mu \mathrm{l} \mathrm{H2O}$ ), $1 \times$ NEBuffer $3+$ one of the studied restriction enzyme. (BamHI and EcoRI; New

\section{Southern blot hybridization}

As a result of a Southern blot analysis, hybridization of a molecular probe to DNA of selected plants carrying $n p t I I$ gene confirmed by PCR was observed. In the control sample, there were no signals manifesting the adding of the probe to gained restriction fragments. A positive control which confirmed plasmid gave a clear impression after hybridization; however, single band showing the presence of $n p t I I$ gene was recognized on autoradiographs (Fig. 8).
B uidA

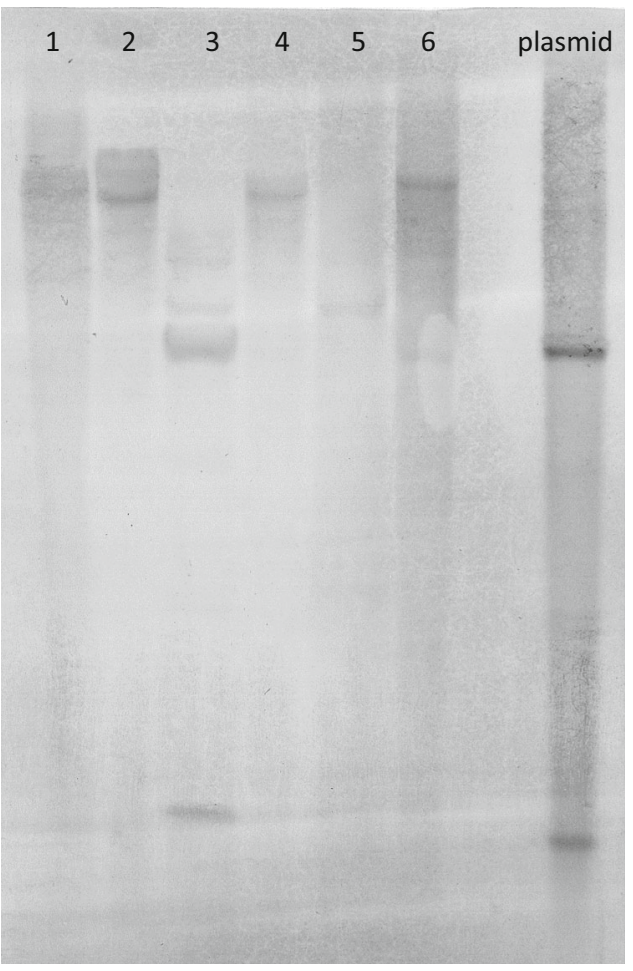

England Biolabs). The digestion temperature: $37^{\circ} \mathrm{C}$ and time: $24 \mathrm{~h}$. DNA separation: $0.9 \%$ agarose gel in $1 \times$ TEB buffer at the presence of voltage; $7 \mathrm{~V} / \mathrm{cm}$ during $5 \mathrm{~h}$. Later, sample was transferred on the nitrocellulose filter and the hybridization was made according Sambrook et al. (1989)

\section{Gentiopicroside content of $G$. tibetica transformants}

Leaves excised from wild plants growing in the field presented a lower percentage of gentiopicrosides than that one originated from an axenic culture. The content of gentiopicroside in leaves of G. tibetica wild form derived from an axenic culture was evaluated to the level of fresh weight of $9.96 \%$. In transgenic plants, it ranged between 6.66 and $12.41 \%$. In their roots, only very low level was found, about $0.46 \%$. Table 3 shows the percentage of 
Table 3 Content of gentiopicroside in leaves of G. tibetica transformants and other gentians originated from axenic and field cultured

\begin{tabular}{lll}
\hline Species & \multicolumn{2}{l}{ Gentiopicroside content $(\%)$} \\
\cline { 2 - 3 } & Field culture & Axenic culture \\
\hline Gentiana cruciata & 0.63 & 4.09 \\
Gentiana kurroo & Not studied & 7.02 \\
Gentiana lutea & 4.28 & 11.17 \\
Gentiana tibetica & & \\
Wild form & 8.23 & 9.96 \\
Genetically modified & Not studied & $6.66-12.41$ \\
\hline
\end{tabular}

${ }^{a}$ According to Polish GMO law, we are not allowed to have transformants on the field culture

gentiopicroside of fresh weight of G. tibetica transformants in relation to the wild form of three other gentians.

\section{Discussion}

\section{Transformation efficiency}

Summing up the aim of already published papers of the gentian transformation systems was established for modifying physiological, pharmaceutical, and horticultural traits. The number of papers presenting genetic transformation is much less limited when A. tumefaciens is used as the transformation vector (Rybczyński et al. 2015). In this paper, leaf blade explants were selected as the object of experiments based on our earlier obtained results indicating high morphogenic potential of a leaf (somatic embryo regeneration) and green leaf mesophyll protoplasts as its single cell (callus and shoot regeneration) (Rybczyński et al. 2007; Fiuk and Rybczynski 2008a, b; Tomiczak et al. 2015, 2016).

The transformation efficiency is very much depending on the criterion of the evaluation. However, for any other experiments, the positive number of transformants is superior value which in carried out experiments brought to final culture on kanamycin selection medium 196 transformants, out of 1250 calluses, confirmed with the help of gus gene expression. Considering the first stage, the percentage of uidA gene expressing calluses was very high, reaching in many experiment combinations even $100 \%$ of total number of calluses regenerated. The transformation efficiency expressed as the total number of regenerants to the number of transgenic callus lines in particular combination of experiments resulted in $0.5-22.5 \%$. With the help of kanamycin selection with 30 and $50 \mathrm{mg} / \mathrm{l}$, the percentage of positive shoot number of PCR reached 3.3 and 5.0\%, respectively, for G. dahurica (Sun and Meng 2010). In case $G$. triflora $\times G$. scabra transformation experiments concerning the effect of constitutive expression of GtMADS gene, five binary vectors were introduced into its genome. Approximately 90 bialophos-resistent calluses were obtained out of 54,000 leaf explants. On regeneration medium, 36 transformants were obtained, each from an independent callus line (Mishiba et al. 2005). Only 17 transgenic plants of cv. Albireo of the same hybrid out of over 10,000 leaf explant were regenerated and grow in vitro until flowering, expressing strong bialaphos herbicide-resistance (Nishihara et al. 2006). The transformation of E. grandiflorum showed that the potentially useful transgene (kanamycin resistance) was present in seven plants derived from independent events of transformation and the presence of the transgenic protein was detected in one of them (Semeria et al. 1996). For non-vector gentian transformation, only G. kurroo (electroporation) and hybrid (G. triflora $\times$ G. scabra) (particle bombardment) were tested with very low transformation efficiency. Only nine transformants, in the presence of kanamycin selection pressure, derived from electroporated embryogenic protoplast are low in comparison to morphogenic potential of untreated protoplasts of G. kurroo (Wójcik and Rybczyński 2015). In the presence of hygromycin selection, only two transgenic hybrid gentian plants were regenerated from each selected callus derived from bombarded suspension cells with plasmid caring gus and hpt genes (Hosokawa et al. 2000).

\section{Strains of Agrobacterium}

For plant transformation, the majority of explored $A$. tumefaciens strains derive from two wild isolates possessing one of two types of chromosomes: C58 or Ach5 (Wróblewski et al. 2005). Among the few studied strains (data not show), only transformation with the help of C58C1 (octopin strain) afforded possibility for obtaining transgenic tissues and transformants of G. tibetica. It is consistent with the negative results describing the transformation of G. triflora $\times$ G. scabra using the strain LBA 4404 of A. tumefaciens (Hosokawa et al. 2000). In the case of species from the family Gentianaceae, it seems that strains possessing Ach5 chromosome are ineffective in this matter. Only genus Gentiana was transformed by strain EHA 101 and EHA 105 descending from C58 isolate (Mishiba et al. 2005; Nishihara et al. 2006). Reports presenting transformations of E. grandiflorum that is related to gentians also likewise concern only strains derived from C58 isolate (Ledger et al. 1997; Semeria et al. 1996). We would like to suggest that an additional factor which could influence the obtained results was the presence of $\mathrm{pCH} 32$ helper plasmid containing virG and virE genes (Hamilton 1997). The increase in transformation efficiency was noted when the mentioned above helper plasmid was introduced 
to A. tumefaciens used for grapevine (Santos-Rosa et al. 2008), lettuce, potato, and Arabidopsis transformation (Wróblewski et al. 2005). For medicinal plants, other than gentians, characterized by very rich secondary metabolism and relative resistance to bacterial material, Drosera rotundifolia (Hirsikorpi et al. 2002) and Artemisia annua (Vergauwe et al. 1996), the strain C58C1 was successfully applied for the genetic modification, too.

\section{Time of bacteria incubation and co-culture}

The time of the incubation plays a crucial role in the transformation efficiency. In the case of gentian transformation, the time of bacteria incubation varied greatly and depended on plant material (species) and the strain of Agrobacterium. The dipping of the leaf explants of $G$. triflora $\times G$. sabra hybrid into bacteria suspension of EHA101 strain was enough to recognize transformation events (callus proliferation), if the co-cultivation lasted for as long as 1 week (Nishihara et al. 2006). The co-cultivation of E. grandiflorum lasted about 2 or $5 \mathrm{~min}$ with incubation time taking 1 or $20 \mathrm{~min}$. In that case, the extension of the time significantly affected the efficiency of the transformation procedure (Ledger et al. 1997; Semeria et al. 1996). In our experiments carried out on G. tibetica, leaf explants presented a relation between the extension of incubation time (up to $24 \mathrm{~h}$ ) and the transient expression of GUS activity. The extension of the time up to $120 \mathrm{~h}$ resulted in total explant expression of GUS activity; however, this plant material had completely lost morphogenic potential and later exhibited necrosis spread across the explant. We conclude that the dying of the explant could be the result of a stress reaction of leaf cells to the long time effect of bacteria on the immunological system of plant material, even that the species is the one of the richest producers of antibacterial secondary metabolites. Moreover, the cross effect of dying cells on the living ones might have occurred, and the overgrowth and development of the surviving cells had no chance to happen (Belny et al. 1997).

In this paper, the highest number of GM callus lines was produced by explants incubated during $30 \mathrm{~min}$ in the presence of $2.0 \mathrm{~g} / \mathrm{l} \mathrm{L}$-glutamine; however, the highest efficiency of transgenic plant regeneration occurred when explants were incubated for $1 \mathrm{~h}$ at the presence of $1.0 \mathrm{~g} / \mathrm{l} \mathrm{L}-$ glutamine. A similar time of incubation and a 5-day-long co-cultivation were successfully used for Echinacea purpurea leaf explant transformation (Wang and To 2004). The time of incubation is usually shorter, even though the species belong to plants of rich secondary metabolites characterized by their bacteriostatic or bacteriocide actions. Here are a few examples: 10 min of incubation and 3 days of co-cultivation for Drosera rotundifolia (Hirsikorpi et al.
2002), 15 min for incubation and 4-day-long co-cultivation for Plumbago zeylanica (Wei et al. 2006), $20 \mathrm{~min}$ of incubation and 5-day-long co-cultivation Camellia sinensis (Sandal et al. 2007), and 30 min of incubation and 4-daylong co-cultivation for Coffea canephora (Hatanaka et al. 1999). It should be emphasized that cell suspension, regardless of its type, requires a considerably longer time of the bacteria incubation, for example: Arabidopsis thaliana 48 h (Gallego et al. 1999) and Nicotiana tabacum even $72 \mathrm{~h}$ (Rempel and Nelson 1995). Most probably, it is the reason that cell wall of external cells of aggregate is thicker than the internal walls of any explant and what is more important is not damaged, so bacteria virulantial action comes cross with obstacles, which takes longer.

\section{The effect of $\beta$-lactam antibiotics (timentin and cefatoxime)}

Both antibiotics used in this experiment are characterized by a specific mechanism of action; they do not have the effect on metabolism of eukaryotic plant cells. There are numerous evidences giving examples of non-destructive effect of $\beta$-lactam antibiotics on eukaryotic organisms (Pollock et al. 1983; Young et al. 1984; d'Utra Vaz et al. 1993; Kaur et al. 2008). However, we should note information on the inhibition action or delayed response of plant explants cultured in the presence of cefatoxime (Cheng et al. 1998; Joersbo et al. 2003; Li et al. 2007). A similar phenomenon was observed in the case of our experiments. In the presence of $250 \mathrm{mg} / \mathrm{l}$ of cefatoxime, over $60 \%$ of explants presented slow dying and only $5.55 \%$ of initial number of explants were capable of callus production. An analogues timentin concentration did not affect the surviving of the explants and callus formation occurred in $35 \%$ of the initial number of explants. In the presence of used plant growth hormones, the response of explant was similar in the case of cefatoxime. However, timentin did not bear a statistically significant effect on callus tissue formation. The affectivity of Populus euphratica regeneration ability significantly decreased in the presence of the antibiotic and the regenerated shoots were etiolated and albinotic. (Ding et al. 2006). A similar response has been described for Dianthus caryophyllus shoot regeneration from leaf blade explants (Estopà et al. 2001).

The last 10 years have witnessed the substituting of cefatoxime by timentin in the plant vector transformation. It has a significant meaning in the case of species in which cefatoxime negatively affects the regeneration processes (Cheng et al. 1998). The timentin may not only stimulate inhibition of the morphogenic response of explant but enhance it as well, which was observed in the case of leaf explants of Dianthus caryophyllus, Lycopersicon esculentum, or Platanus acerifolia (Estopà et al. 2001; Li et al. 
2007; Mamidala and Nanna 2009a, b). We would like to stress that such test of the effect of $\beta$-lactam antibiotics on morphogenetic potential has never been done before for gentians and more so their leaf explants. For gentians, carbenicillin and cefatoxime were the most often used (Hosokawa et al. 1997; Momčilović et al. 1997; Vinterhalter et al. 1999). And so, very low efficiency of transformation events may be the reason for the presence of cefatoxime in the medium (Vinterhalter et al. 1999; Chen et al. 2010), which will be in agreement with the results described in this paper.

\section{L-Glutamine effect on transformation efficiency}

L-Glutamine is the one of the organic substances tested for improving the vector transformation efficiency for monocots (Kubota et al. 2013) and for plant species with very rich secondary metabolites; Camellia sinensis (Sandal et al. 2007). It acts into two fields of relation between the bacteria and plant cell. L-Glutamine affects the effectiveness of transformation by protection of the bacterial cell against plant polyphenols and protects bacterial abilities to transfer the fragment of T-DNA (Sandal et al. 2007) into a plant cell. Very efficient Agrobacterium-mediated transformation of the liverwort Marchantia polymorpha thalli was developed with the help of L-glutamine used for co-cultivation medium (Kubota et al. 2013). Additional L-glutamine to Agrobacterium infection medium counteracted the bactericidal effect of Pogostemon cablin and significantly increased the T-DNA delivery to its leaf explants (Paul et al. 2012). In our studies, L-glutamine appeared an essential factor for obtaining callus tissue and plants presenting stable transgenesis. The leaf explants with Agrobacterium without L-glutamine in the medium did not form callus tissue in selection conditions. The highest number of T0 plants was regenerated in the presence of $1.0 \mathrm{~g} / \mathrm{l} \mathrm{L}$-glutamine; however, the highest number of explants expressing blue staining of X-Gluc reaction was noted with $2.0 \mathrm{~g} / \mathrm{l}$ of the factor.

\section{Test of transformation stability}

We are very sorry that the most interesting part of plant transformation work it means genetic stability of T0 and next generations is out of us. In Poland, according the present law, we are not allowed to do transformation experiments outside of the lab. We received government permission to work on gentian transformation only in laboratory. Our objective of experiments G. tibetica, the plant species only adopted to Polish environmental, is characterized by at least 2-3 years of vegetative growth outside to build proper root system, what insure the growth of shoots and blooming. Therefore, we do not have next generations. However, we ought to say that regenerants of some Gentianaceae species are able to give precocious flowering in both: axenic and multiplication culture. The phenomenon might occur spontaneously or appears under cytokinin control (Krestić-Milošević et al. 2015). According to our long-term culture experiences with wild form and transformants of G. tibetica, the species is not able to blooming in vitro culture. In references, there is not information about functionality of gametes of gentians flowers obtained in vitro.

\section{Conclusions}

In this paper, the system of G. tibetica transformation with the help of vector-A. tumefaciens strain C58C - carrying helper plasmid $\mathrm{pCH} 32$ was used for production of transformants. The leaf blade explant as the source of relatively uniform cell population responded to co-culture with bacteria by callus tissue formation. The transformation efficiency depended on the L-glutamine concentration and time of the co-culture. The regeneration system based on the application of kanamycin selection and bacteria elimination from explants and later transformant cultures using timentin and cefatoxime has been developed. On molecular level, the transformation was confirmed with the help of PCR and Southern blot hybridization analysis.

Taking into consideration our experiences with established gentian embryogenic cell suspensions in plant regeneration of numerous gentians, we would like to announce a next paper that will describe their transformation with the help of A. tumefaciens.

Author contribution statement The following declaration about authors' contributions to the research has been done: laboratory experiments- $\mathrm{AW}$, writing of the manuscript—JJR.

Acknowledgements Funding was provided by Polish Government, Ministry of Science and Higher Education (Grant No. N N302 139035).

Open Access This article is distributed under the terms of the Creative Commons Attribution 4.0 International License (http://crea tivecommons.org/licenses/by/4.0/), which permits unrestricted use, distribution, and reproduction in any medium, provided you give appropriate credit to the original author(s) and the source, provide a link to the Creative Commons license, and indicate if changes were made.

\section{References}

Belny M, Hérouart D, Thomasset B, David H, Jacquin-Dubreuil A, David A (1997) Transformation of Papaver somniferum cell suspension cultures with sam1 from A. thaliana results in cell 
lines of different S-adenosyl-L-methionine synthetase activity. Physiol Plant 99:233-240

Bijelović A, Rosić N, Miljuš-Djukić J, Ninković S, Grubišić D (2004) In vitro regeneration and transformation of Blackstonia perfoliata. Biol Plant 48:333-338

Chen Y-T, Fanf Q-S, Chiang C-H, Yeh S-D, Wu H-W, Yu T-A (2010) Transgenic Eustoma grandiflorum expressing the bar gene are resistant to the herbicide Basta. Plant Cell Tissue Organ Cult 102:347-356

Cheng ZM, Schnurr JA, Kapaun JA (1998) Timentin as an alternative antibiotic for suppression of Agrobacterium tumefaciens in genetic transformation. Plant Cell Rep 17:646-649

d'Utra Vaz EB, dos Santos AVP, Manders G, Cocking EC, Davey MR, Power JB (1993) Plant regeneration from mesophyll protoplasts of the tropical woody plant passionfruit (Passiflora edulis cv. Flavicarpa Degener) the importance of the antibiotic cefatoxime in the culture medium. Plant Cell Rep $12: 220-225$

Ding X, Chen X, Li W, Du Z (2006) Effects of antibiotics on plantlet regeneration via organogenesis in Populus euphratica. For Stud China 8:27-31

Dong JZ, McHughen A (1993) An improved procedure for production of transgenic flax plant using Agrobacterium tumrfaciens. Plant Sci 88:61-71

Estopà M, Marfà V, Melé E, Messeguer J (2001) Study of different antibiotic combinations for use in the elimination of Agrobacterium with kanamycin selection in carnation. Plant Cell Tissue Organ Cult 65:211-220

Fiuk A, Rybczyński JJ (2008a) Factors influencing efficiency of somatic embryogenesis of Gentiana kurroo (Royle) cell suspension. Plant Biotech Rep 2:33-39

Fiuk A, Rybczyński JJ (2008b) Genotype and plant growth regulatordependent response of somatic embryogenesis from Gentiana spp. leaf explants. In Vitro Cell Dev Biol Planta 44:90-99

Gallego ME, Sirand-Pugnet P, White CI (1999) Positive-negative selection and T-DNA stability in Arabidopsis transformation. Plant Mol Biol 39:83-93

Gamborg OL, Miller RA, Ojima K (1968) Nutrient requirements of suspension cultures of soybean root cells. Exp Cell Res 50:151-158

Giovannini A, Pechioni N, Allavena A (1996) Genetic transformation of lisianthus (Eustoma grandiflorum Griseb.) by Agrobacterium rhizogenes. J Genet Breed 50:35-40

Hamilton CM (1997) A binary-BAC system for plant transformation with high molecular weight DNA. Gene 200:107-116

Handa T, Sugimura T, Kato E, Kamada H, Takayanagi K (1995) Genetic transformation of Eustoma grandiflorum with rol genes. Acta Horticult 392:209-218

Handa T (1992) Regeneration and characterization of prairie gentian (Eustoma grandiflorum) plants transformed by Agrobacterium rhizogenes. Plant Tissue Cult Lett 9:10-14

Hatanaka T, Choi YE, Kusano T, Sano H (1999) Transgenic plants of coffee Coffea canephora from embryogenic callus via Agrobacterium tumefaciens-mediated transformation. Plant Cell Rep 19:106-110

Hirsikorpi M, Kämäräinen T, Teeri T, Hohtola A (2002) Agrobacterium-mediated transformation of round leaved sundew (Drosera rotundifolia $\mathrm{L}$.). Plant Sci 162:537-542

Hosokawa K, Matsuki R, Oikawa Y, Yamamura S (1997) Genetic transformation of gentian using wild type Agrobacterium rhizogenes. Plant Cell Tissue Organ Cult 51:137-140

Hosokawa K, Matsuki R, Oikawa Y, Yamamura S (2000) Production of trangenic plants by particle bombardment of suspensionculture cells. Plant Cell Rep 19:454-458

Ishimaru K, Sudo H, Satake M, Matsumaga Y, Hasewaga Y, Shimomura K (1990) Amarogentin, amaroswerin and four xanthones from hairy cultures of Swertia japonica. Phytochemistry 29:1563-1565

Jefferson RA, Kavanagh TA, Bevan MV (1987) GUS fusions: $\beta$ glucuronidase as a sensitive and versatile gene fusion marker in higher plants. EMBO J 6:3901-3907

Joersbo M, Jørgensen K, Brunstedt J (2003) A selection system for transgenic plants based on galactose as selective agent and UDPglucose:galactose-1-phosphate uridyltransferase gene as selective gene. Mol Breed 11:315-332

Kaur A, Gill MS, Ruma D, Gosal SS (2008) Enhanced in vitro shoot multiplication and elongation in sugarcane using cefatoxime. Sugar Tech 10:60-64

Krestić-Milošević D, Vinterhalter B, Janković T, Vinterhalter D (2015) Biotechnology and phytochemistry of Gentianella species from the central regions of the Balkan Peninsula. In: Rybczyński JJ, Davey MR, Mikula A (eds) The Gentianaceae, vol 2., Biotechnology and ApplicationSpringer, Berlin, pp 93-112

Kubota A, Ishizaki K, Hosaka M, Kohchi T (2013) Efficient Agrobacterium transformation of the liverwort Marchantia polymorpha using regenerating thalli. Biosci Biotechnol Biochem 77:167-172

Ledger SE, Deroles SC, Manson DG, Bradley JM, Given NK (1997) Transformation of lisianthus (Eustoma grandiflorum). Plant Cell Rep 16:853-858

Li ZN, Liu GF, Fang F, Bao MZ (2007) Adventitious shoot regeneration of Platanus acerifolia Willd. facilitated by timentin, an antibiotic for suppression of Agrobacterium tumefaciens in genetic transformation. For Stud China 9:14-18

Mamidala P, Nanna RS (2009a) Influence of antibiotics on regeneration efficiency in tomato. Plant Omics J 2:135-140

Mamidala P, Nanna RS (2009b) Efficient in vitro plant regeneration, flowering and fruiting of dwarf tomato cv. Micro-Msk. Plant Omics J. 2:98-102

Menković N, Šavikin-Fodulovic K, Vinterhalter D, Grubišić D (2000) Secoiridoid content in hairy roots of Gentiana punctata. Pharm Pharmacol Lett 10:73-75

Mikuła A, Rybczyński JJ (2001) Somatic embryogenesis of Gentian genus. I. The effect of the preculture treatment and primary explant origin on somatic embryogenesis of Gentiana cruciata (L.), G. pannonica (Scop) and G. tibetica (King). Acta Physiol Plant 23:15-25

Mikuła A, Wesołowska M, Kapusta J, Skrzypczak L, Rybczyński JJ (1996) Cytomorphological studies on somatic embryogenesis of Gentiana tibetica (King) and G. cruciata (L.). Acta Soc Bot Pol 65:47-51

Mishiba K, Nishihara M, Nakatsuka T, Abe Y, Hirano H, Yokoi T, Kikuchi A (2005) Consistent transcriptional silencing of 35Sdriven transgenes in gentian. Plant J 44:541-556

Mishiba K-I, Nishihara M, Abe Y, Nakatsuka T, Kawamura H, Kodama K, Takesawa T, Abe J, Yamamura S (2006) Production of dwarf potted gentians using wild-type of Agrobacterium rhizogenes. Plant Biotech 23:33-39

Momčilović I, Grubiśić D, Kojić M, Nešković M (1997) Agrobacterium rhizogenes-mediated transformation and plant regeneration of four Gentiana species. Plant Cell Tissue Organ Cult $50: 1-6$

Murashige T, Skoog F (1962) A revised medium for rapid growth and bioassays with tobacco tissue culture. Physiol Plant 15:473-497

Nishihara M, Nakatsuka T, Hosokawa K, Yokoi T, Abe Y, Mishiba K-I, Yamamura S (2006) Dominant inheritance of white flowered and herbicide-resistant traits in transgenic gentian plant. Plant Biotech 23:25-31

Paul A, Bakshi S, Sahoo DP, Kalita MC, Sahoo L (2012) Agrobacterium-mediated genetic transformation of Pogostemon cablin (Blanco) Benth. using leaf explants: bactericidal effect of leaf 
extracts and counteracting strategies. Appl Biochem Biotech 166:1871-1895

Piątczak E, Królicka A, Wysokińska H (2006) Genetic transformation of Centaurium erythraea Rafn by Agrobacterium rhizogenes and the production of secoiridoids. Plant Cell Rep 25:1308-1315

Pollock K, Barfield DG, Shields R (1983) The toxicity of antibiotics to plant cell culture. Plant Cell Rep 2:36-39

Quing YY, Yang W, Hong XS, Ling XX (2006) Study on the genetic transformation of gentian by gene recombinant. Nat Sci 4:60-67

Rempel HC, Nelson LM (1995) Analysis of conditions for Agrobacterium-mediated transformation of tobacco cells in suspensions. Transgenic Res 4:199-207

Rybczyński JJ, Borkowska B, Fiuk A, Gawrońska H, Śliwińska E, Mikuła A (2007) Effect of sucrose concentration on photosynthetic activity of in vitro cultures Gentiana kurroo (Royle) germlings. Acta Physiol Plant 29:445-453

Rybczyński JJ, Davey RD, Tomiczak K, Niedziela A, Mikuła A (2015) System of plant regeneration in gentian in vitro culture. In: Rybczyński JJ et al (eds) The Gentianaceae, vol 2., Biotechnology and applicationsSpringer, Berlin, pp 1-44

Sandal I, Saini U, Lacroix B, Bhattacharya A, Ahuja PS, Citovsky V (2007) Agrobacterium-mediated genetic transformation of tea leaf explants: effects of counteracting bactericidity of leaf polyphenols without loss of bacterial virulence. Plant Cell Rep 26:169-176

Santos-Rosa M, Poutaraud A, Merdinoglu D, Mestre P (2008) Development of a transient expression system in grapevine via agro-infiltration. Plant Cell Rep 27:1053-1063

Semeria L, Ruffoni B, Rabaglio M, Genga A, Vaira AM, Accotto GP, Allavena A (1996) Genetic transformation of Eustoma grandiflorum by Agrobacterium tumefaciens. Plant Cell Tissue Organ Cult 47:67-72

Skrzypczak-Pietraszek E, Skrzypczak L, Wesołowska M (1993) Gentiana tibetica King from tissue culture. Sci Pharm 61:287-296

Sambrook J, Fritsch EF, Maniatis T (1989) Molecular cloning: a laboratory manual, Chapter 9, 2nd edn. Cold Spring Harbor Laboratory Press, Cold Spring Harbor, pp 9-62

Subotić A, Budimir S, Grubišic D, Momcilović I (2003/2004) Direct regeneration of shoots from hairy root cultures of Centaurium erythraea inoculated with Agrobacterium rhizogenes. Biol Plant 47:617-619

Suginuma C, Akihana T (1995) Transformation of gentian with Agrobacterium rhizogenes. Acta Horticult 392:153-160

Sun S-B, Meng L-S (2010) Genetic transformation of Gentiana dahurica Fish. by Agrobacterium tumefaciens using zygotic embryo-derived callus. Acta Physiol Plant 32:629-634
Takahashi M, Nishihara M, Yamamura S, Nishizawa S, Irifune K, Morikawa H (1998) Stable transformation of Eustoma grandiflorum by particle bombardement. Plant Cell Rep 17:504-507

Tiwari RK, Trivedi M, Guang ZC, Guo G-Q, Zheng GC (2007) Genetic transformation of Gentiana macrophylla with Agrobacterium rhizogenes: growth and production of secoiridoid glucoside gentiopicroside in transformed hairy root cultures. Plant Cell Rep 26:199-210

Tomiczak K, Mikuła A, Śliwińska E, Rybczyński JJ (2015) Autotetraploid plant regeneration by indirect somatic embryogenesis from leaf mesophyll protoplasts of diploid Gentiana decumbens L. In vitro Cell Dev Biol 51:350-359

Tomiczak K, Śliwińska E, Rybczyński JJ (2016) Comparison of the morphogenic potential of five Gentiana species in leaf mesophyll protoplast culture and ploidy stability of regenerated calli and plants. Plant Cell Tissue Organ Cult. doi:10.1007/s11240016-1000-y

Vergauwe A, Cammaert R, Vandenberghe D, Genetello C, Inzé D, Van Montagu M, Van der Eeckhout E (1996) Agrobacterium tumefaciens-mediated transformation of Artemisia annиa L. and regeneration of transgenic plants. Plant Cell Rep 15:929-933

Vinterhalter B, Orbanović V, Vinterhalter D (1999) Transgenic root culture of Gentiana punctata L. Acta Soc Bot Pol 68:275-280

Wang H-M, To K-Y (2004) Agrobacterium-mediated transformation in the high value medicinal plant Echinacea purpurea. Plant Sci 166:1087-1096

Wei X, Gou X, Yuan T (2006) A highly efficient in vitro plant regeneration system and Agrobacterium-mediated transformation in Plumbago zeylanica. Plant Cell Rep 25:513-521

Wesołowska M, Skrzypczak L, Dudzińska R (1985) Rodzaj Gentiana L. w kulturze in vitro. Acta Pol Pharm 42:79-83

Wróblewski T, Tomczak A, Michelmore R (2005) Optimization of Agrobacterium mediated transient assays of gene expression in lettuce, tomato and Arabodopsis. Plant Biotech J 3:259-273

Wójcik A, Rybczyński JJ (2015) Electroporation and morphogenic potential of Gentiana kurroo (Royle) embryogenic cell suspension protoplast. Biotechnology 96(1):19-29

Xiang C, Han P, Lutziger I, Wang K, Oliver DJ (1999) A mini binary vector series for plant transformation. Plant Mol Biol 40:711-717

Young PM, Hutchins AS, Canfield ML (1984) Use of antibiotics to control bacteria in shoot cultures of woody plants. Plant Sci Lett 34:203-209

Zhang HL, Xue SH, Pu F, Tiwari RK, Wang XY (2010) Establishment of hairy root lines and analysis of gentiopicroside in the medicinal plant Gentiana macrophylla. Russ J Plant Physiol $57: 110-117$ 